\title{
ArcheoSciences
}

Revue d'archéométrie

33 (suppl.) | 2009

Mémoire du sol, espace des hommes

\section{The spatial organization of the Phoenician city of Amrith (Syria)}

\section{Michel Al Maqdissi and Christophe Benech}

\section{Q OpenEdition \\ 1 Journals}

\section{Electronic version}

URL: https://journals.openedition.org/archeosciences/1596

DOI: 10.4000/archeosciences.1596

ISBN: 978-2-7535-1599-4

ISSN: 2104-3728

Publisher

Presses universitaires de Rennes

Printed version

Date of publication: 30 October 2009

Number of pages: 209-211

ISBN: 978-2-7535-0943-6

ISSN: 1960-1360

\section{Electronic reference}

Michel Al Maqdissi and Christophe Benech, "The spatial organization of the Phoenician city of Amrith

(Syria)", ArcheoSciences [Online], 33 (suppl.) | 2009, Online since 30 October 2011, connection on 01

February 2022. URL: http://journals.openedition.org/archeosciences/1596 ; DOI: https://doi.org/

10.4000/archeosciences. 1596 


\title{
The spatial organization of the Phoenician city of Amrith (Syria)
}

\author{
Michel Al Maqdissi* and Christophe Benech **
}

Key words : Magnetic survey, Excavations, Phoenician site, City planning, Syria.

The site of Amrith is located on the Syrian coast $6 \mathrm{~km}$ south of the modern city of Tartous. More ancient occupation, from the end of the 3th millennium B.C., has been identified on the tell but Amrith is first of all known as a typical site of the Phoenician period in Syria. The site is believed to be a suburb of the city of Aradus on the neighboring island, today called Arwad. It is known primarily for its temple from the 6th century B.C., and its necropolis, but the great extent of the site and the variety of its archaeological structures (e.g. religious buildings, stadium, workshops and harbour) clearly show that Amrith was a flourishing city and may have an important commercial role.

Apart from the main monuments which have been excavated (Fig. 1), Amrith is still almost unknown and we have very poor information about its organization. The main sectors have been identified even if little is known about their internal organization yet. The site is surrounded by important necropolis (the population of Aradus was buried here also), which give an idea of the limits of the city. The site is crossed by two rivers, a fact possibly linked to the religious tradition of Amrith in which the water has an important role: the Nahr el Amrith, which runs past the main temple (Ma'abed), and the Nahr el Kuble, not far from the place where the Syrian archaeological mission has discovered a second temple.

Excavations have revealed an important zone of workshops, which remains to be explored. Until now, domestic archi- tecture has been identified mainly on the 'tell', but there are probably other quarters with private houses.

The environment of the site is menaced by a high estate pressure. Some parts of the site are already condemned but the essential is still preserved as farmland, even if agricultural activities also cause damage to archaeological structures. The study of Amrith by geophysical survey is being developed in collaboration with the Project PROGECESA (Geophysical survey and study of ancient urban centers of Syria), financed by the French National Agency of Research.

\section{FiRST RESUltS WITH MAGNETIC SURVEY}

Different parts of the site have been carried out by magnetic survey with a cesium gradiometer from Geometrics. The aim of this first campaign was to approach the organization of the city around the main known buildings and, after assessment of the quality of the resulting magnetic maps, to see on what basis it will be possible to study the spatial organization of the city of Amrith.

\section{Sector of the tell (Fig. 2)}

The first tests concerned at the bottom of the tell of Amrith and sought to reveal whether the occupation levels excavated on the top of the tell continue beyond. The magnetic map

* Direction Générale des Antiquités et Musées de Syrie.

** UMR 5133 Archeorient, Maison de l'Orient et de la Méditerranée. 
Figure 1: Satellite view (Google) of the site of Amrith with the location of main monuments and magnetic surveys.

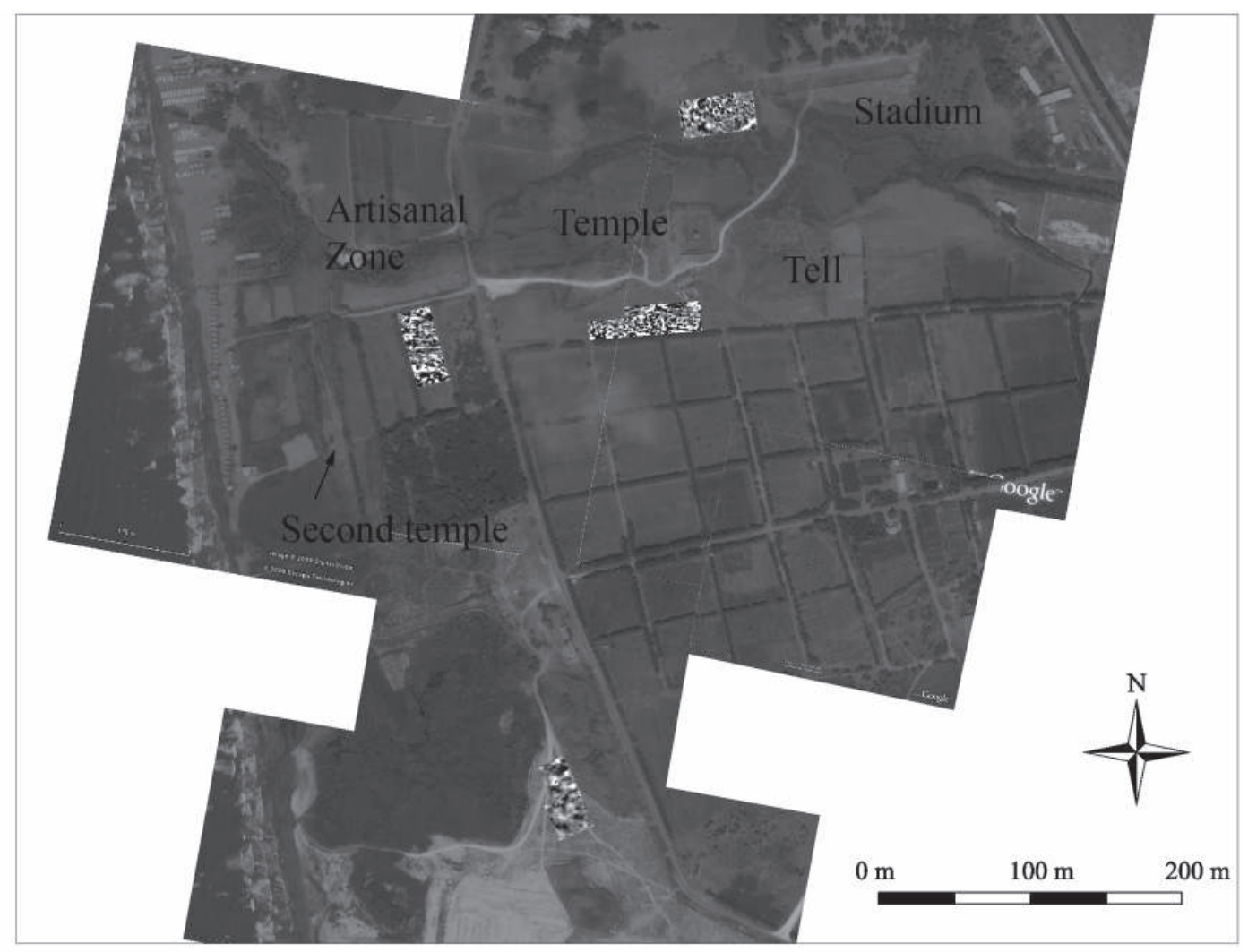

Figure 2: Magnetic survey at the bottom of the tell.

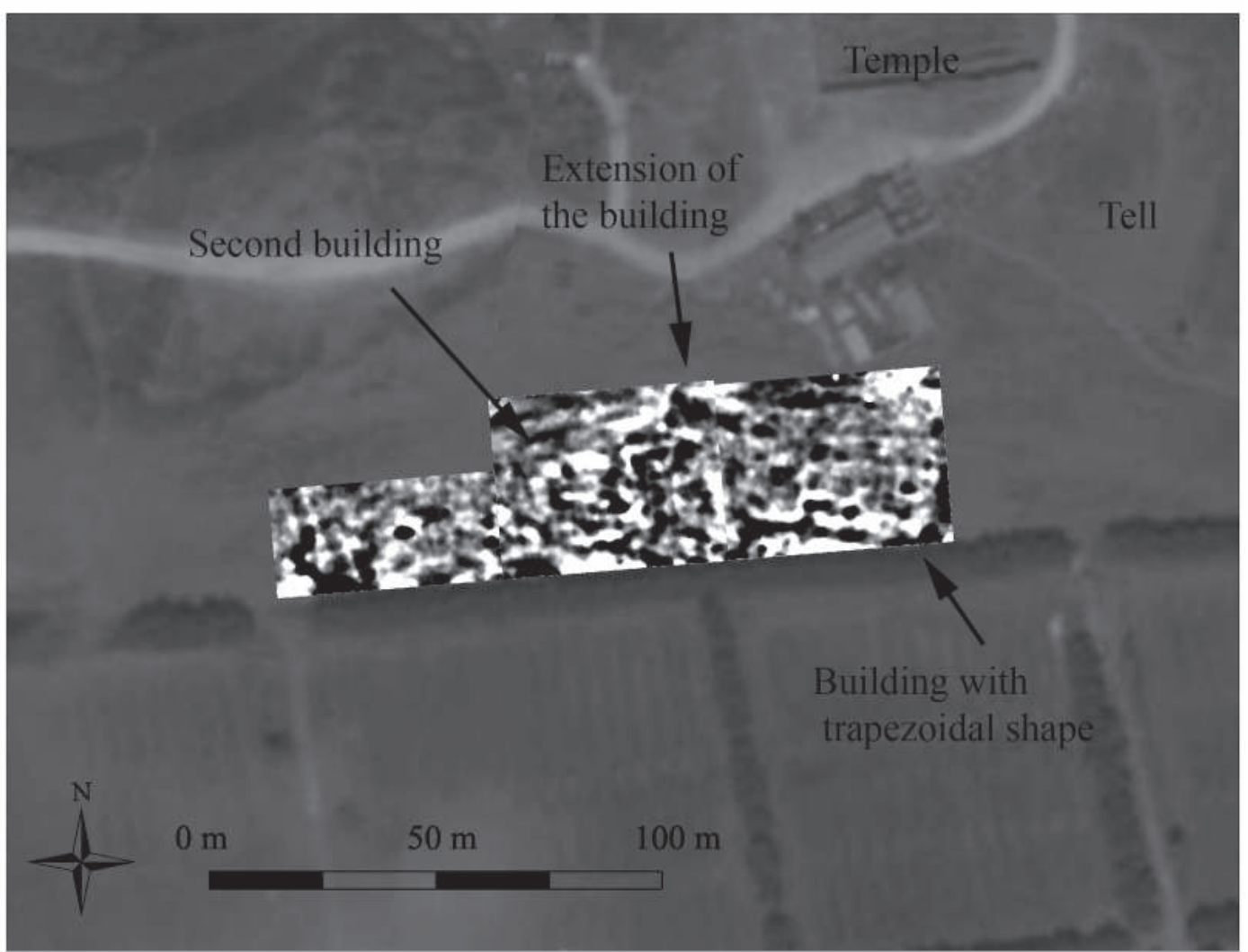

ArcheoSciences, revue d'archéométrie, suppl. 33, 2009, p. 209-211 
shows a relatively complex and disturbed context: archaeological structures seem to be in relatively poor state of preservation and their organization indicates probably different states even if it is still difficult to separate these.

The occupation is relatively dense, as on the tell, and seems to continue beyond the surveyed area, particularly to the south. This southern sector could be the position of the towncentre of the city of Amrith. A central location is indicated by the configuration of the site with to the north the sector of the temple and the stadium, to the north-east the workshop zone, to the east the second temple and the harbour and to the south and east the necropolis.

\section{The workshop zone (Figure 3)}

A second test was made in the workshop zone, not far from excavated areas which have revealed kilns and ditches. In this case also the archaeological structures seem to be not wellpreserved but they are intelligible. The magnetic map revealed the existence of a wide, square building - probably a warehouse - measuring around $42 \mathrm{~m}$ on each side. The details of the plan are not clear but it seems to be composed of a wide central courtyard surrounded by small square rooms. The southern part of the map is more disturbed but the magnetic anomalies of this sector could correspond to ditches such as those found a few meters away in the excavations.

\section{Perspectives}

These first results show that extension of the geophysical surveys in Amrith would be valuable, even if the environmental conditions are not always optimal and the preservation of archaeological structures is not very good. Despite this, the site offers a unique opportunity to study a Phoenician city practically preserved in its entirety. Unlike other important Phoenician cities along the coast, Amrith has not disappeared under a modern city. The various modern installations on the site will be an obstacle to a complete comprehension of Amrith but it is possible to obtain enough information to identify the main features of town planning at a crucial period, just before the beginning of the expansion of Hellenistic cities.

\section{Bibliography}

Dunand, M. and Saliby, N., 1985. Le temple d'Amrith dans la Pérée d'Aradus, Geuthner: Paris.

Rey-Coquais, J.-P., 1974. Arados et sa Pérée aux époques grecque, romaine et byzantine. Recueil des témoignages littéraires anciens, suivi de recherches sur les sites, l'histoire, la civilisation, Geuthner: Paris.

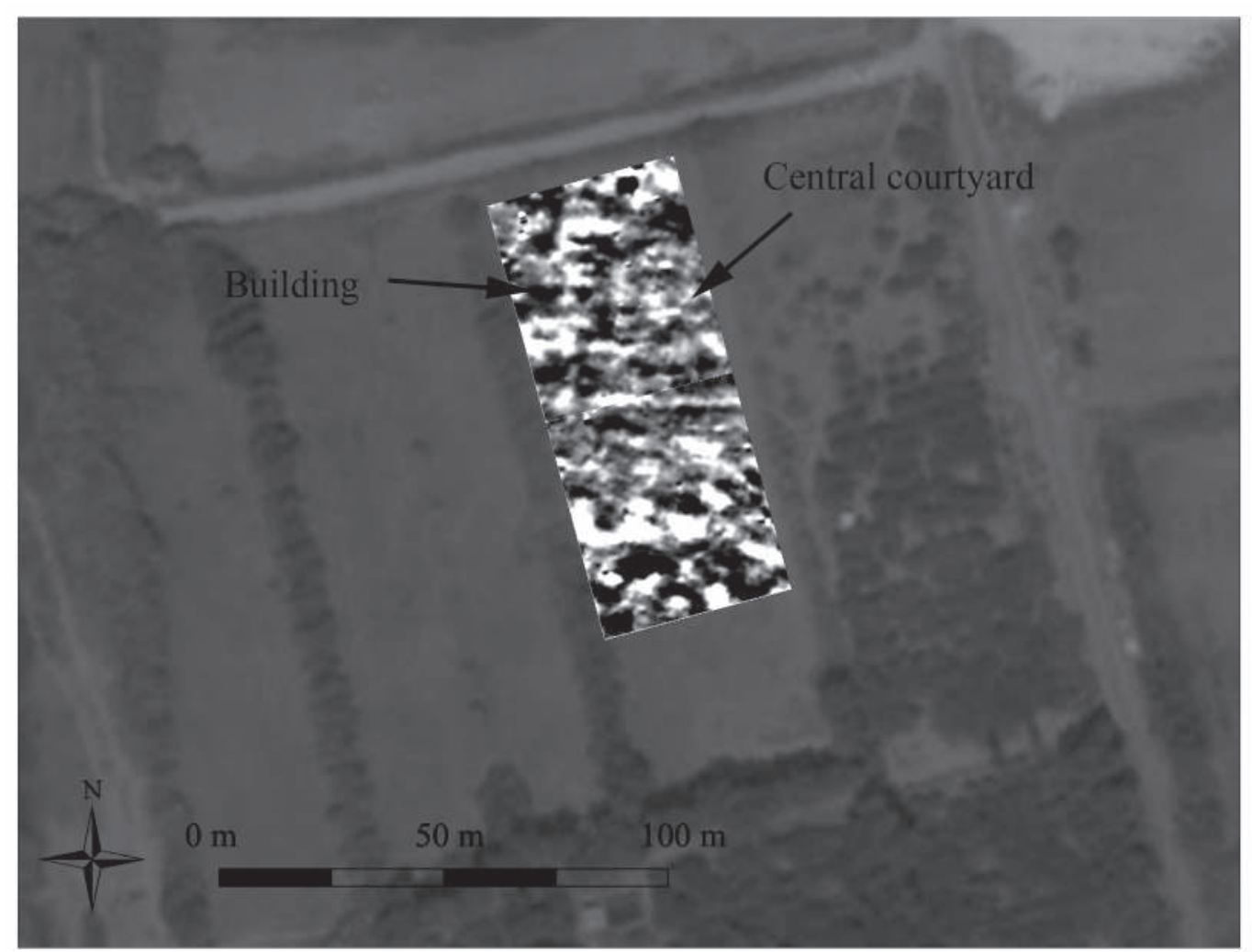

Figure 3: Magnetic survey in the artisanal zone. 